\title{
TESTAMENTARY GIFTS TO "ISSUE" :
}

\section{MIERRILL I. SchNEBLY}

While the construction of the word "issue" has given rise to a vast amount of litigation, there is comparatively little to be found upon the subject in our American legal literature, either in the more general treatises upon real property and upon wills, or in special papers published in the legal periodicals. And there is particularly lacking a discussion of certain observable tendencies to be discerned in the more recent cases dealing with this problem. Ledwith v. Huist, ${ }^{1}$ decided last June by the Supreme Court of Pennsylvania, well illustrates the difficulty involved. The material facts of the case were these: a testator gave realty in trust, the income to be paid to his wife, Caroline Buchmiller, and his daughter, MTary Ledwith, in equal shares during their lives, and to the survivor for her life; after the death of the survivor the income was given "to the issue and descendants of my said daughter, MIary Ledwith, if any, per stirpes, for and during their natural lives, and the life of the survivor of such issue and descendants; and in the event of the death of my said daughter, Mary Ledwith, without leaving issue and descendants, then at that time, or upon the death of the last of such issue or descendants, if any, I order and direct my executors to sell, etc." Then followed a provision that the proceeds of such sale should be equally divided among several named charities. All of the limitations above recited were held to fail; and the property passed under the laws of intestacy to the widow and daughter mentioned, as heirs. The court declared that there was a "flagrant violation" of the Rule against Perpetuities, and that the life estates of the widow and daughter were so intimately connected with the general scheme that the whole must fail. A correct construction was of particular inportance in this case, because upon it hinged the application of the Rule against Perpetuities. As a consequence of the construction adopted, not only the gift to the issue failed, but also the several benefactions to charity limited thereafter.

Six constructions for the word "issue" will be stated and discussed, and in connection with each the hule against Perpetuities will be considered if applicable. From the discussion of these several constructions it will be the writer's aim to develop certain principles which will point the way toward the desirable result in the case above mentioned.

\footnotetext{
$*$ The writer desires to acknowledge his indebtedness to Professor W. $\mathbf{R}$. Vance of Yale University Law School for many lind suggestions and criticisms made during the preparation of this article.

I (1925, Pa.) 130 Atl. 315.
} 
First Construction: In a Testamentary Gift to "Issue" Folm lowing a Particular Gift to the Ancestor, the Word "Issue" May Be a Word of Limitation, Creating an Estate Tail in the Ancestor of the Issue Where the Gift Is of Realty, and an Absolute Interest Where the Gift Is of Personalty. As the foregoing statement indicates, this construction is possible only in the case where the devise or bequest to the issue is in the form of a remainder after a particular estate in the ancestor. The typical case is a devise to "A for life, and after his death to his issue." Here the Rule in Shelley's Case will operate to create an estate tail in' A, in the absence of a restraining context.

All lawyers are more or less familiar with the distinction taken between "words of purchase" and "words of limitation". It is the function of the former to point out "purchasers",nate the donees who take the gift directly from the donor; of the latter, to delimit or describe the quantum of the estate which passes. $^{2}$ In the days before any estate in fee could be alienated so as to defeat the heir, there were no words of limitation; what we would now term such were really words of purchase. "Heirs" and "heirs of the body" were intended to indicate a series of persons taking directly from the donor, the estate of any one depending on that of his predecessor only in the sense that his relationship to such preceding holder fixed his right to the succession. $^{3}$ After the rule became established in the feudal law that the heir general could be defeated by a conveyance of the ancestor in the latter's lifetime, "heirs" lost its original significance; it now served merely to indicate that the estate conveyed was of such a sort that it would pass to the heir general if not alienated by the ancestor, and that it would likewise pass to the heir of any alienee to whom the first holder might transfer it. ${ }^{4}$ The word had now become one of "limitation". By a somewhat similar process of development the phrase "heirs of the body" also lost its original force as a strict expression of "purchase", and became in effect merely one of "limitation", designating an estate of such a sort as would pass, not to the heir general, but to the lineal heir only, if the entail was not docked by one of the permissible methods. ${ }^{5}$ It is perhaps apparent from the foregoing discussion that words of limitation always contain within themselves the idea of this series of persons related to one another in the prescribed manner, so as to be able to succeed

21 Preston, Estates, 35-6, 38; Williams, Real Property (22d ed. 1014) 147; 1 Tiffany, Real Property (2d ed. 1920) 44-5.

32 Blackstone, Commentaries, ${ }^{*}$ 56-7; Williams, op. cit. 66-9; Leake, Property in Land (2d ed. 1909) 23.

${ }^{4}$ Leake, loc. cit.; Williams, op. cit. 352; Tiffany, op. cit. 44-5.

. W Williams, op. cit. 147-8, 352; Leake, op. cit. 25-6, 134. 
to the gift; or, as we would now say, who can take from one another by descent. ${ }^{\circ}$

In approaching the problem of construing the word "issue", it is highly important to consider the nature of the instrument in which the word is used. In a deed creating only legal interests as distinguished from equitable, "issue" is always a word of purchase. ${ }^{7}$ This construction follows necessarily from the rule, the historical origin of which is suggested in the preeeding paragraph, that the word "heirs" is just as essential to the creation of a fee tail inter vivos as it is to a fee simple. No other word suffices. While the requirement of words of limitation for a conreyance in fee by deed has been abrogated in most jurisdictions by statute, the common law rule that "issue" in such an instrument shall be construed as a word of purchase still remains. The word "heirs" was never indispensable in a will, however, for any words indicating the intention to create a fee simple or fee tail were sufficient to accomplish that end. Conreyances creating equitable interests, such as marriage settlenents, were construed rather after the manner of wills than of deeds when necessary to effect the purpose of such an instrument. ${ }^{\circ}$

The word "issue", when used in a testamentary disposition, has often been said to be prima facie the equivalent of "heirs of the body", and, therefore, a word of linitation. "The term embraces descendants of every degree whensoever existent, and, unless restricted by the context, cannot be satisfied by being applied to descendants at a given period. The only mode by which a devise to the issue can be made to run through the whole line of objeets comprehended in the term is by construing it as a word of limitation synonymous with heirs of the body, by which means the ancestor takes an estate tail; an estate capable of comprising in

- See Williams, op. cit. 148.

- Coke, Littleton, $\approx 20 \mathrm{a}$; Blackstone, op. cit. supre note 3 , at 115 ; Mals:piece v. Fletehe; (1785, C. P.) Comyns, 457; Mcllhinay i. MICIlhinang (1894) 137 Ind. 411, 37 N. E. 147; Price i. Sisson (1860) 13 N. J. Eq. 163 (aff'd in W'eenarnken Feroy Co. i. Sisson, 1861, 17 N. J. Eq. 475). Sez also Ginger $d$. White v. Whitc (1742, C. P.) Willes, 348; Katght to. Eltis (1789, Ch.) 2 Bro. C. C. 5570 , 578 ; Doc d. Coopcr ‘. Collin (1791, K. B.) 4 T. R. 294; Parton v. Lefferts (1831, Pa.) 3 Rawle, 59; Rudlivis a. Rand (1914) 88 Conn. 292, 91 Atl. 198 (holding that "deseendants" is not sufficient in a deed to make an estate tail); $A d a$ ars ${ }^{\prime}$. Ross (1860) 20 N. J. L. 505 ("children" not sufficient).

The rule in South Carolina is now contrary. Williems 2. Gease (1909) 83 S. C. 265,65 S. E. 241 . Formerly the decisions were in accord with the usual rule. Marliley $v$. Singlctary $(1860$, S. C.) 11 Rich. Eq. 898. Sce also, Dick v. Ricleer (1906) 222 Ml. 413,78 N. E. 823.

8 Leake, op. cit. supra note 3 , at 126 ; Williams, op. cit. sugre note 2 , at 259.

a 1 Preston, op. cit. supra note 2, at 392; 1 Horenden, Supplincirt to Vesey Junior's Reports, 54 . See also Williams, op. cit. supita note 2 , at 185-6. 
its devolution, though not simultaneously, all the objects embraced by the word 'issue' in its largest sense." 10 That this is the view of the English cases is clear. ${ }^{11}$ Doubtless this idea of the equivalency of "issue" and "heirs of the body" arose out of the constant use of "issue" in limiting a remainder after a fee tail; "to $A$ and the heirs of his body, and if $A$ dies without issue, then, etc.", was the regular formula. In accordance with this rule of prima facie construction, a devise to "A and his issue" normally creates an estate tail in $A ;{ }^{12}$ and a devise to "A for life, and after his death to his issue", normally creates an estate tail in A by operation of the Rule in Shelley's Case. ${ }^{13}$ If it suffciently appears from the context that "issue" was intended to be a word of purchase, it will be so construed; the attempt is to effectuate the intention of the testator as indicated in his language. ${ }^{14}$ As the principles of construction are not precisely the same with respect to the use of "issue" in bequests of personalty, there will first be considered its meaning in devises of land.

Where the accompanying context justified the inference that "issue" was intended to be a word of purchase, even a devise to "R. R. and his issue, lawfully begotten", was construed as giving but a life estate to R. R..$^{15}$ There was in that case a failure of

102 Jarman, Wills (6th Am. ed. 1893) 403.

11 Ibid; Leake, op. cit. supra note 3, at 137; Theobald, Wills (7th ed. 1908) 412; Woodhouse v. Herrick (1855, Ch.) 1 K. \& J. 352; Kavanagh v. Morland (1853, Ch.) Kay, 16; Roddy v. Fitzgerald (1857) 6 H. L. Cas. *823.

12 Leake, loc. cit. supra note 11; Theobald, loc. cit. supra; Parlin v. Kritight (1846, Ch.) 15 Simons, 83. A recent American case is Packer's Estato (1914) 246 Pa. 116, 92 Atl. 70.

${ }^{13}$ Leake, op. cit. supra note 3, at 138; Theobald, op. cit. supra note 11, at 422; Woodhouse v. Herrick, supra note 11; Kavanagh v. Morland, supra note 11; Roddy v. Fitzgerald, supra note 11.

14 "There is, however, a third class of cases where a testator uses in his will an expression, in its ordinary use not of a technical nature, and capable of more meanings than one. . . . The first point, therefore, to be considered is-whether 'issue' be a word of this nature. Now we think that this sufficiently appears, from referring to the various authorities . . . . In all of them it is treated as a word capable of being used in different senses, either as including all descendants, in which case it is of course a word of limitation, or as confined to immediate descendants, or some particular class of descendants living at a given time. Probably it will be found most frequently used in the former sense, and it therefore most frequently has the effect of giving an estate tail to the ancestor. It might even, perhaps, be conceded that this is prima facie its meaning. But the authorities clearly shew, that whatever be the prima facie meaning of the word 'issue', it will yield to the intention of the testator to be collected from the will; and that it requires a less demonstrative context to show such intention, than the technical expression of 'heirs of the body' would do." Alderson, B., in Lees v. Mosley (1836, Exch.) 1 Y. \& C. 589, 607, 608.

For similar expressions of judical attitude, see Ginger $d$. White $v$. Whito, supra note 7; Doe d. Cooper v. Collis, supra note 7.

${ }^{15}$ Hockley v. Mawbey (1790, Ch.) 1 Ves. Jr. 143. See also 2 Jarman, 
issue at the death of $R . R . ;$ but it is clear that the court regarded the limitation as creating a contingent remainder in favor of the issue as purchasers. Courts have felt much less difficulty in construing "issue" as a word of purchase than in similarly interpreting "heirs of the body".." The context which will induce construction as a word of purchase must contain words of distribution, as that the issue shall take equally, or as tenants in common, or equivalent expressions inconsistent with the idea of the issue taking successively as tenants in tail. Superadded words of limitation are not usually sufficient by the English rule. ${ }^{17}$ Formerly it was required that there be also words adequate to carry a fee to the issue $;^{18}$ but this is no longer necessary in England, as under the Wills Act of 1837 every devise without qualification gives a fee simple if the testator has one. Similar statutes are common in this country. The rule of construction subsequently to the Wills Act in England has been thus summarized: "Every devise to a person for life, and after his decease to his issue, in words which direct or imply distribution

op. cit. supra note 10, at 406; Theobald, op. cit. supra note 11 . Compare a recent American case, Rhode Island Hospital Trust Co. 2. Bridghan (1919) 42 R. I. 161, 106 Atl. 149.

16 See extract from the opinion of Alderson, B., supra note 14; Karanagh v. Morland, supra note 11; Woodhouse $v$. Herricl, supra note 11; the opinions of Channell, B., Watson, B., Crompton, J., and Lord Wensleydale in Roddy v. Fitzgerald, supra note 11; Powcll 2 . Board of Domcstic Missions (1865) 49 Pa. 46; Timanus v. Dugan (1876) 46 Md. 402; Nes थ. Ramsay (1893) $155 \mathrm{~Pa}$. 628, 26 Atl. 770; Daniel v. Whartenby (1873, U. S.) 17 Wall. 639.

For illustrations of the difficulty felt in the English courts with respect to the construction of "heirs of the body" as words of purchase, sze Jfsson v. Wright (1820, H. L.) 2 Bligh, 1; Jordan 2 . Adams (1861) 9 C. E. (N. s.) $* 483$. Miny of the American decisions evince a more liberal attitude in construing "heirs" or "heirs of the body". See Actna Life Insusance Co. v. Hoppin (1914, C. C. A. 7th) 214 Fed. 928 ("the heirs of the body of S., their heirs and assigns" held to be words of purehase in a remainder); Blythe v. Goode (1920, C. C. A. 4th) 269 Fed. 544 (lilse the preceding case); Simonton 2 . White (1899) 93 Tex. 50, 53 S. W. 389 ("bodily heirs" construed as "children"); Mills v. Thomo (1886) 95 N. C. 362 ("heirs" held a word of purchase). See also Carlton 2. Price (1851) $10 \mathrm{Ga} .495$ (bequest of slaves to $A$. for life, with gift over to his "heirs of the body"; held that A. took only a life estate and not the absolute property).

17 A summary of the English cases may be found in a Jarman, op. cit. supra note 10, at 416. Superadded words of limitation descriptive of heirs of the same species as the "issue" did not make "issue" a word of purchase. Ibid. at 409. Nor did a limitation to the heirs general of the issue. Ibid. at 410 . But superadded words of limitation which narrowed the course of descent did convert "issue" into a word of purchase. So where there is a limitation to "A for life, and after his death to his issue, and to the hcirs male of such issue". Ibid. at 414-5.

18 Woodhouse $v$. Herrich, supro note 11; Roddy 2. Fitzgerald, supra note 11. That words of distribution together with words sufficient to earry a 
between the issue, gives the issue an estate in fee in remaindor by purchase." 19

A study of the English cases suggests a grave doubt whether the courts of that country have really observed the solicitude for the intention of the testator which they have so often professed. ${ }^{20}$ At a time when, and in a country where, estates tail were so common as to be familiar, even in respect to their peculiar phraseology of creation, to laymen as well as to lawyers, it was perhaps a fair rule that prima facie "issue" was intended. to be a word of limitation. And yet one wonders if any testator since the fifteenth century ever actually intended words in $a$ remainder limited after a life estate expressly given to be words of limitation effective to make a fee tail in the one named as tenant for life. It is certainly hard to understand why the English courts should have required such overwhelming evidence of a contrary intention. Why were not superadded words of limitation, alone, enough? Or words of distribution, alone ? ${ }^{21}$

The American courts have almost uniformly acquiesced in the English rule that in a will "issue" is prima facie a word of limitation. $^{22}$ Because of the statutes, before mentioned, making every unqualified devise pass a fee simple, it is believed that many of

fee to the issue were enough: Loes v. Mosley, supra note 14; Greanwood v. Rothwell (1843, C. P.) 5 M. \& Gr. 628.

192 Jarman, op. cit. supra note 10 , at 422 .

${ }^{20}$ In Ginger $d$. White $v$. White, supra note 7 , at 351 , Willes, C. J., said: ". . . Why does the word issue in a will signify the same as heirs of the body? Only because it may be supposed that the testator, who was ignorant of the law, intended it should have that construction. It does not therefore vi [ex] termini create an estate tail in a will as 'heirs of the body' do in a deed, but only where it appears to be the intent of the testator that the word should have that construction, or at least that it does not appear that the intent of the testator was otherwise.

"In order therefore to find out what" construction is to be put upon the words of a will, we ought in the first place to consider what the intent of the testator is, though this I am afraid is too often the last thing that is thought of."

21 It may be noted that the English courts have not always seemed satisfied with their rule of prima facie construction. Several judges have expressed the view that the popular meaning of "issue" is "children". Seo the opinions of James and Brett, L.JJ., in Ralph v. Carricl (1879, C. A.) 11 Ch. D. 873; In re Hickey [1917, C. A.] 1 Ch. D. 601 . On this point compare the following American cases: Soper v. Brown (1892) $136 \mathrm{~N}$. Y. 244, 32 N. E. 768; Rhode Island Hospital Trust Co. v. Bridgham, supra note 15 .

22 So, a limitation to "A and after his death to his issue" normally creates an estail tail in A. Gonzales v. Barton (1873) 45 Ind. 295; Gardner v. Anderson (1924) 114 Kan. 778, 116 Kan. 431, 227 Pac. 743; Zubriskie v. Wood (1872) 23 N. J. Eq. 541; Wright v. Gaskill (1908) 74 N. J. Eq. 742, 72 Atl. 108; Kingsland v. Rapelye (1834, N. Y.) 3 Edw. Ch. 1; Kleppner v. Laverty (1871) 70 Pa. 70; Armstrong v. Michener (1894) 160 Pa. 21, 28 Atl. 447; Grimes v. Shirl (1895) 169 Pa. 74, 32 Atl. 113; Stayman v. Paxson (1908) 221 Pa. 446, 70 Atl. 803; Hall's Ex'r v. Smith 
our American decisions can be brought within the English rule requiring words of distribution together with language sufficient to pass the fee. ${ }^{23}$ That any American tribunal should be more insistent upon a construction creating an estate tail than the English courts would be, seems incomprehensible; yet that has oceasionally been the fact." On the whole the American view has been more liberal. Thus, in a number of jurisdictions words of limitation superadded have been held sufficient in themselves to make "issue" a word of purchase."s Besides the presence of

(1874, Va.) 25 Grat. 70; Stolies v. Tan Wycl (1887) 83 Ya. 724, 3 S. E. 387. See also Powell v. Board of Domcstic Mrssions, sumra note 16; Timernus v. Dugan, supra note 16; Ward v. Jones (1848) 10 N. C. 100 ; Gadsdcn v. Desportes (1892) 39 S. C. 131, 17 S. E. 706.

23 Where both words of distribution and superadded words of limitation appear, the result is, of course, clear. A good illustration of this type of case is Powell v. Board of Domestic Missions, supra note 16. There the devise was to A. for life, and "if he shall die leaving lawful issue, then to the said issue, if one, to him or her, his or her heirs and assigns forever, but if more than one, to be equally divided amongst them, their heirs and assigns forever." Robins v. Quizlizen (1875) 79 Pa. 333 is a particularly clear case; there was a devise to A. for life, and after her death "to her issue and their heirs forever, in the proportions to which they would be entitled under the intestacy laws of Pennsylvania, respectively, ete." Other cases are Abbott v. Jeinlinins (1823, Pa.) 10 Serg. \& R. 206; Gourdin $v$. Deas (1887) 27 S. C. 479,4 S. E. 64 . In the following cases there were words of distribution alone: Hill 2 . Gilcs (1902) 201 Pa. 215, 50 Atl. 753; Ward v. Jones, supra note 22.

21 In Kingsinnd $v$. Rapelye, supra note 22, there was a gift of realty to a daughter for life, and then "to the lawful issue of my said daughter, his, her and their heirs, executors, administrators and assigns furcecr, equally to be divided among them, shaie and share alite." It was held that the daughter took an estate tail, the court evidently misundergtanding the English decisions. Grimes 2u. Shirl, supra note 22, was a case of a remainder "to her lawful issue; to have and to hold the same in common to them, their heirs and assigns forcrer:" The court thought that the words "in common" were not sufficient words of distribution.

Gardner v. Anderson, supra note 22, is a notewortiny recent cace. T. gave the residue of his real and personal property to his daughter $G$. for life, and then provided: "Should my daughter G. marry and have issue, then I direct that at her death my property shall descend to them equally, share and share alike." On a bill to construe the will, it was held that the daughter took a fee tail in the realty and an absolute interest in the personalty. And this in spite of the fact that the statutes provided that every conveyance of real estate should pass the entire interest of the grantor unless restricted to a lesser estate (Kan. Gen. Sts. 1901, sec. 1202), and also provided for abrogation of the Rule in Shelley's Case where the remainder was limited to the "heirs".

${ }_{25}$ Shreve v. Shreve (1875) 43 MId. 382; Timanus a. Dugen, sugre nots 16; McIntyre v. McIntyre (1881) 16 S. C. 290; Boyllin 2". Ancinen (1887) 28 S. C. 186; Daniel v. Whartenby, supra note 16. Contra: Gouzales e?. Barton, supra note 22; Zabirislie v. Wood, s'pre note 22 (a five to four decision); Tright v. Gaskill, supra note 22; Paston i. Lefferts, supro note 7; Hall's Ex'r 2. Smith, supro note 22; Stolses 2: I"en Wycli, supjo note 22 . 
words of distribution and superadded words of limitation, there is an indefinite number of other contexts which may induce a court to adopt the purchase construction. Some of these have occurred frequently enough to merit notice. In Shaw $v$. Weigh $h^{20}$ the English House of Lords decided that an estate tail was created although the remainder was limited to the issue if the life tenant died "leaving issue". ${ }^{27}$ In Wilkins $v$. Rowan"s the Nebraska court reached a different conclusion in a case where there was similar language; but there were also the words "in fee simple", and the primary ground for the decision is not clear. In Pennsylvania it seems to be the rule that "leaving issue" does not rebut the prima facie presumption of an estate tail, although "leaving issue him surviving" does rebut it. ${ }^{30}$ Where a remainder is limited to the issue of the life tenant who may be "living at his death", it seems that the issue take as purchasers and the Rule in Shelley's Case does not apply. ${ }^{31}$ Likewise, where the remainder is conditioned upon the issue attaining a specified age, the Rule does not apply. ${ }^{32}$ In Leightner $v$. Leightner ${ }^{33}$ the testator devised to two persons for their lives and after the death of either to his issue. There was a further provision that the interests given should be held in trust until the two life tenants should attain the age of twenty-five, and that with the written consent of the trustees either might "sell his interest . . . to the other in fee simple." The court declared that this provision would be meaningless if "issue" was construed as a word of limitation, with the consequence of creating a fee tail which the

\footnotetext{
26 (1760, K.B. \& H.L.) 2 Stra. 798.

27 Compare the English decisions holding that a gift over on death "without leaving issue" refers to a general failure of issue in the case. of land. Forth $v$. Chapman $(1720$, Ch.) 1 P. Wms. 663. The tendency of the American decisions is to the contrary. Smith v. Kimbell (1894) 153 III. 368,38 N. E. 1029.

28 (1921) 107 Neb. 180, 185 N. W. 437.

29 Kleppner v. Laverty, supra note 22; and see Nes v. Ramsuy, supra note 16. But see Hay v. Hay (1852, S. C.) 4 Rich. Eq. 478.

${ }^{30}$ Nes v. Ramsay, supra note 16. Compare Armstrong v. Michencr, supra note 22. In that case there was a gift to the issue of the life tenant, "if he shall so have, and if none then (over)". It was held that an estate tail had been created.

${ }^{31}$ Gadsden v. Desportes, supra note 22 (remainder after death of life tenant to his male issue "then living"). And see Wistar v. Scott (1884) $105 \mathrm{~Pa} .200$; Hay v. Hay, supra note 29; Cushney v. Henry (1834, N. Y.) 4 Paige, 345. There is a suggestion in accord in Lethieullier v. Tracy (1754, Ch.) 3 Atk. 784, at 796. Compare University of Oxford v. Clifton (1759, Ch.) 1 Eden, 473 , where a devise to " $\mathrm{A}$ and his issue living at his death" was held to create an estate tail in A.

${ }^{32}$ Helm v. Frisbie (1877) 59 Ind. 526; Way v. Gest (1825, Pa.) 14 Serg. \& R. 40.

${ }^{33}$ (1878) 87 Pa. 144.
} 
statute would convert into a fee simple. In Shaltcis $v$. Ladd the testator made a gift of land to $H$. and to "her heirs and assigns", and further stipulated that at her death it should "be enjoyed by the lawful issue of (H.), excepting that if F. B. S. shall survive his wife (H.), he shall during his lifetime enjoy the rents . . . of one-third of the said cstate." It was held that $\mathrm{H}$. took but a life estate, the decision being put upon the ground that the testator had expressly excluded the husband's curtesy: and had given him an entirely different lind of interest, thus indicating an intention not to create in $\mathrm{H}$. an estate to which curtesy would be incident; a fee tail in $\mathrm{H}$. would be converted by statute into a fee simple, and the husband would talie curtesy.

The statutes which abrogate the Rule in Shelley's Case do not, it is presumed, require the courts to hold "issue" to be a word of purchase where it is clear that the testator intended it as one of limitation. But it seems doubtful whether a court in a jurisdiction where such a statute exists will ever be satisfied as to such intent on the part of the testator: ${ }^{: 3}$ Very little can b3 said today in support of the rule of prima facie construetion as a word of limitation, particularly in view of the general abolition of fees tail.

It remains to notice in connection with devises to issue the case of Rembert $v$. Vetoe.si The testator devised to M. A. R. for life, and then "to such of her issue as she may leave living", the property to be "equally divided among such issue". Doubtless there was enough in this language to warrant the court in interpreting the word "issue" as one of purchase. But the decision was rested upon a somewhat different ground. It was said that "issue" was a word of limitation equivalent to "heirs of the body", but that no one could take as an heir of the body inless he was an heir under the statute of descents as well as 3

34 (1891) 141 Pa. 349, 21 Atl. 596.

s Compare Taylor v. Taylor (1870) $63 \mathrm{~Pa}$. 481, where there was a gift for life, with remainder to the issue of the life tenant if she should die "leaving issue", and to their heirs and assigns; and a further provision that if the life tenant should die without leaving issue, the estate should be sold by the executors after the death of the tcstator's wife (who was a co-devisee with the life tenant), and the proceeds divided among named persons. The court said there was a remainder to the "children" of the life tenant; but all that it was necessary to decide was that no estate tail was created.

36 See the following cases where the decision was based upon such a statute: Bamett v. Bamett (1S94) 104 Calif. 298, 37 Pac. 1019 (remainder to the "issue and heirs of the body" of the life tenant); Williams v. Angell (1862) 7 R. I. 145 (remainder to the issue "in equal portions and to their heirs and assigns forever"). See also Sopcr 2. Botoviz, sujore note 21 , where the statute was not mentioned (words of distribution present).

s: (1911) 89 S. C. 198,71 S. E. 959. 
lineal descendant. One is obliged to conclude that the court did not mean what it said when it declared that issue was a word of "limitation".

Where "issue" is used in a gift of personalty, it may be construed as a word of limitation; and it has been said that such is its prima facie meaning, even in that case. So, in Lyon v. Mitchell $^{38}$ where the testator directed that a residue of personal estate be divided equally among his sons "share and share alike, as tenants in common, and to the issues of their several and respective bodies", it was held that the sons took an absolute interest in the residue. ${ }^{30}$ And the general rule that words which in a devise of land would create an estate tail, in a bequest of chattels give the absolute interest, has often received recognition in this country.40 But where a life estate in the personalty is expressly limited, with a remainder to the issue, the tendency of the cases both English and American is to construe "issue" as a word of purchase. Thus, in Knight $v$. Ellisis where the income of a fund of money was left to T. B. for life, "and after" his decease . . . to the issue male of my said grandnephew (T. B.)", it was held that the issue took as purchasers.42 It is to be noted that there were no words of distribution applied to the issue. That the decision represents a sound view as to the proper interpretation of the word "issue" in such a gift is hardly to be doubted. Personal property cannot be entailed; it is un- likely that any testator would have intended "issue" under such circumstances to be a word of limitation. Moreover, the Rule in Shelley's Case does not apply to gifts of personalty as a rule of law, ${ }^{43}$ so that there is sufficient freedom to attain the desired re-

38 (1816, Ch.) 1 Mad. 467.

39 Plumer, V. C., said: "It is a general rule that, whenever the Words of a Will, used in a Bequest of Personal Property, would, if applied to Real Property, give an Estate Tail, they pass an absolute Interest in Personalty, unless the Testator shows a clear intention that they should not be so construed. There can be no doubt that the words in this Will would, if they had been applied to Real Property, have given an Estate Tail to the four Sons. Is there then any apparent intention in this Testator that the words of this Will should not have the effect of passing absolute Interest to the Sons? . . . Prima facie the words give an absolute Interest; and the onus lies upon the other side to show circumstances that lead to a different conclusion."

${ }^{40}$ Woodley v. Findlay (1846) 9 Ala. 716; Ward v. Jones, supra note 22.

H1 Supra note 7.

42 Lord Chancellor Thurlow said: "It must have occurred to the judges who have decided those cases, that, under the idea of making the rules of decision as to leasehold estates analogous to those which are applied to estates of inheritance, the intention of the testator must be much oftener disappointed than carried into effect, and, then, there is no wonder that the Court should try to get out of the technical rule by any means it can."

H3 It is sometimes said that the Rule in Shelley's Case applies by analogy to gifts of personalty, but this seems to mean, more properly speal- 
sult even were the words "heirs of the body" used instead of the supposedly non-technical word "issue". There are several decisions in this country in which "issue" "s and even "heirs of the body" *5 have been construed as words of purchase in a bequest of chattels. And in many cases the possibility of an estate tail, or absolute interest, in the ancestor has not been considered." Some of this latter class of decisions may be influenced by the fact that the Rule in Shelley's Case had been abolished in the jurisdictions before the date of the cases. At least one court has gone so far as to declare that in a will "issue" is prima facie a word of purchase.st There are a few cases in which the court

ing, that the same result may be reached as a matter of construction of intent. See 2 Jarman, op. cit. supra note 10, at 331-3; Theobald, op. cit. supra note 11, at 477; Kales, Future Intcrests (1920) sec. 494.

4 Woodley v. Findlay, supra note 40 ("to the lawiul issue of her body, that may be then living, to them and each of them, share and share alile, their heirs and assigns forever"); Mygcrs 2 . Andcrson (1847, S. C.) 1 Strobh. Eq. 344 ("to be the absolute property of the issue of their bodies forever"); Hancocli v. Butler (1858) 21 Tex. 804 ("to his lowful issue forever").

${ }^{45}$ Prescott v. Prescott's Hcirs (1849, Ky.) 10 B. MIon. 56 ("to be equally divided between the heirs lawfully begotten of her body"); Carltorl :Price, supra note 16, ("to the lawfully begotten heirs of his body", with a provision for emancipation of the slaves which were the subject-matter of the gifit in the event of the death of the life tenant without an "heir").

For the peculiar and inconsistent results reached where "heir" or "hoirs of the body" are used in gifts of personalty, see Kales, op. cit. sumpot note 43 , at sees. 436-8.

46 Eaton v. Eaton (1914) 88 Conn. 286, 91 Atl. 196; Middlctorm Thust Co. v. Gaffey (1921) 96 Conn. 61, 112 Atl. 689; Jaclison i. Jacl:son (1891) 153 MIass. 374, 26 N. E. 1112; Paliner v. Hoin (1881) 84 N. Y. 516; Schmidt v. Jewett (1909) 195 N. Y. 4S6, 8S N. E. 1110; Mattcr of Latwcince (1924) 238 N. Y. 116, 144 N. E. 361; Pcarce v. Riclard (1803) 1s R. I. 142. Some of the cases cited in note 49 infir may also be of this class.

In Schmidt v. Jevett, supio, the intention to give to the issue as purchasers was peculiarly clear, for the gift was "to her legal issue in equal portions after they severally reach the full age of tuenty-one years." Note a similar provision in Middletown Trust Co. 2. Gaffey, supra.

In Nice's Estate (1910) $227 \mathrm{~Pa} .75,75$ Atl. 1025, there was a bequest of personalty in a residuary clause which also carried realty. The language was "to her issue, but should she die without issue, ete." One ground of decision was that "die without issue" as applied to perconalty imported a definite failure of issue living at the death of the first donee, and made "issue" a word of purchase. The contention that the construction should be governed by the rule applicable to devises breause there was a gift of the mixed residue was rejected.

si Middletown Trust Co. v. Gaffey, supra note 46. While the case involved a gift of personalty, there was nothing to indicate that the court intended its remark to be limited. It is doubtless an illustration of the growing tendency to treat "issue" as a word of purchase whenever and wherever possible. There seems to be an intimation to the same efrect in Hancock v. Butler, supra note 44. 
has failed to differentiate between realty and personalty with respect to the effect of "issue" in the gift of a mixed residue."

There is a large class of cases in which the testator has left the benefit of a trust to " $A$ " for life, and then directed that at the death of "A" it be divided among "A's" issue. Usually it is not possible to ascertain from the report of the case whether the trust property consisted wholly of personalty, or of realty and personalty mixed; and whether there was or was not a direction to convert any realty which it may have comprised. Practically without exception "issue" has been construed in these cases as a word of purchase, without discussion of the alternative.99 . It would seem that these decisions are right, without respect to the question whether or not the Rule in Shelley's Case had been abolished. As has already been pointed out, that Rule can apply here only as a rule of construction. Regardless of the make-up of the trust res, the testator does not, as a rule, think of it as realty in any sense. Since he almost certainly considers it as personalty, his language should be construed accordingly. Where the trust property consists entirely of realty, the result should be governed, of course, by the principles previously discussed.

The full consequences of construing "issue" as a word of limitation are well illustrated in Ledwith $v$. Hurst.00 There the trust res consisted entirely of realty, which was to be kept intact for several lives. If it should be decided that "issue" was intended as a word of limitation, the result would be to create an estate tail in Mary Ledwith, subject to the life interest of her mother in one-half. This estate tail would be converted by the statute into a fee simple. ${ }^{51}$ The gifts to charities which follow the de-

18 Gardner v. Anderson, supra note 22; Kingsland v. Rapelye, supra note 22. But see Nice's Estate, supra note 46.

${ }^{49}$ Stamford Trust Co. v. Lockwood (1922) 98 Conn. 337, 119 Atl. 218; Stephens v. Jodon (1923) 79 Ind. App. 596, 139 N. E. 293; KKing v. Savago (1876) 121 Mass. 303; Dexter v. Inches (1888) 147 Mass. 324, 17 N. E. 551; Matter of Farmers' Loan and Trust Co. (1914) 213 N. Y. 168, 107 N. E. 340 ; In re Laurence's Estate (1920, Surro. Ct. N. Y. Co.) 111 Misc. 524, 181 N. Y. Supp. 498; Matter of Durant (1921) 231 N. Y. 41, 131 N. E. 562 (for report of this case in the Appellate Division, see (1920, 1st Dept.) 193 App. Div. 80, 183 N. Y. Supp. 339). Doubtless some of the above cases could be brought within the rule applied in connection with gifts of realty, because of the presence of words of distribution. So, Dexter v. Inches, In re Lawrence's Estate, and Matter of Durant.

Frequently the trust cases contain a direction that the trustee shall "divide among" or "distribute among" the issue. This would sufficiently indicate the intention to make "issue" a word of purchase; but a moro direction/ to "pay to" or to "turn over to" or to "transfer to" would not seem enough, as no division is necessarily indicated by such langunge.

so The facts are fully stated supra note 1.

-1 Pa. Sts. 1920, secs. 8323, 10256. 
vise to the issue would doubtless fail, then, being non-vested limitations on a general default of issue.

But apparently the court did not in this case adopt the "limitation" construction. Nor would such an interpretation be permissible in the face of the fact that the limitation was to the issue "for aind during the term of their natural lives". Such a restriction upon the quantum of the estate granted clearly indicated that the testator had in mind descendants or issue of Mary living at a particular time. In White $\%$. Collins ${ }^{52}$ the testator gove lands to his son, F. MI., and then "to the heir male of his body lawfully begotten, during the term of his natural life", and for want of such heir, to his daughters. It was held that F. MI. did not take a fee tail; the words "heir male of the body" were words of purchase descriptive of the person to talke in remainder. The court considered the question as settled by A'chci's Case.: ${ }^{\circ}$ So also in Pedder v. Hunt, wh where the testator gave land to his eldest son for life, and declared that it should thereafter be enjoyed by "the oldest surviving heir of my oldest surviving son then living for their life or lives forev'cr". The court denied the contention that Thomas, who was the oldest surviving son of the testator, took an estate tail, because the limitation to the "heir" was for life only. 55

Second Construction: "Issue" in a Wrill May Combine the Idoa of Limitation with That of Purchase, Creating in the PGison First Answering the Description "Heir of the Body" an Estatc Tail in Realty, and an Absolute Interest in Pcisonalty. There are some instances in which the same words serve the double purpose of pointing out purchasers and at the same time delimiting the quantum of the estate given. So, where there is a gift to the "heirs of A", or to the "heirs of the body of A", without any gift of a life estate to A himself, a fee simple or fee tail, as the case may be, is created in the person first answering the description "heir" or "heir of the body"."s Similarly, a gift to "issue" without any estate in the ancestor preceding, might be held to pass a fee tail in realty, or an absolute interest in personalty, to the person first answering the description "heir of the body". But the decisions in England are against such a

\footnotetext{
52 (1719, C. P.) Comyns, 289.

55 (1597, C. P.) 1 Co. $\approx 66 \mathrm{~b}$.

5* (1887) 18 Q. B. D. 565.

55 It would appear that the principle of these cases fairly covers $L c d$ with v. Hurst, supra note 1 . There was also an additional factor in that case which may be thought to have a bearing in this connection. The issue were to take "per stirpes". This shows that the testator contemplated the possibility of different generations of issue taling concurrently. This would not happen, probably, if "issue" be talien as a vord of limitation equivalent to "heirs of the body".

se Leake, op. cit. supra note 3, at 121; 2 Jarman, op. cit. supro note 10, at 69.
} 
construction. In Freeman v. Parsley ${ }^{57}$ a testator gave personalty to E. R., in case of her death "to be equally divided between her lawful issue, share and share alike". E. R. predeceased the testator. There survived the testator two children of E. R., children of a deceased child, and children of a living child. It was held that the children and grandchildren of E. R. all took per capita. In Cook v. Cook $k^{58}$ the testator devised to "the issue cf J. S." It was held that all issue living at the death of the testator took, but took only life estates. The American cases are to the same effect. ${ }^{5}$ There seems to be, therefore, no authority for making the word "issue" combine in itself the ideas of purchase and limitation. Moreover, so far as the writer knows, it has never been held that any word or words combined these ideas where a life estate to the ancestor preceded. In such a situation, if the idea of limitation was thought to be contained in "issue", the word was construed exclusively as one of limitation, creating the estate tail in the ancestor. ${ }^{60}$

Third Construction: "Issue" in a Will May Include the Whole Line of Descent and Give Life Estates Successively to the Heir's of the Bodyn for the Time Being. Strange as such a proposition may seem, it would appear that this was actually the idea of the Pennsylvania court in Ledwith $v$. Hurst. ${ }^{01}$ In Pedder v. Hunt, supro, ${ }^{62}$ the court thought it the intention of the testator to create a series of life estates, each vesting in the heir for the time being

57 (1797, Ch.) 3 Ves. 421.

os (1706, Ch.) 2 Vern. 545.

"9 In the following American cases there was a gift to the issue without any preceding gift to the ancestor, and it was not suggested that the word could be construed otherwise than as one of purchase: Union Safe Deposit and Trust Co. v. Dudley (1908) 104 Me. 297, 72 Atl. 166; Hills v. Barnard (1890) 152 Mass. 67, 25 N. E. 96; Green v. Hussey (1917) 228 Mass. 537, 117 N. E. 798; Ernst v. Rivers (1919) 233 Mass. 9, 123 N. E. 93; Gardiner v. Everett (1922) 240 Mass. 536, 134 N. E. 372; Petry v. Petry (1919, 1st Dept.) 186 App. Div. 738, 175 N. Y. Supp. 30, aff'd 227 N. Y. 621, 125 N. E. 924. The above were all cases of gifts in trust, the exact composition of the trust res not appearing. See discussion of the trust cases in the text, supra.

In Wistar v. Scott, supra note 31 , the testator gave a lot to his daughters for life, and then to "the male issue, then living, of my son R., their or his heirs and assigns in fee." The court declared that although "issue" was primarily a word of limitation, the context here showed it to be one of purchase. Stress was put upon the words "then living". There was no suggestion that an estate tail might have been created in the issue of $R$. living at the death of the daughters.

oo Even if the will in Ledwith v. Hurst, supra, had been construed as creating an estate tail in the issue of Mary living at her death, the only effect would have been to give such issue a fee simple under the statute previously referred to, and to leave no room for the application of the Rule against Perpetuities so far as the issue were concerned.

61 Supra note 1.

c2 Supra note 54. 
of the eldest surviving son of the testator. Perhaps the language employed in that will warranted the inference. In Parfitt $i$. Hembers the limitation was "to my said nephews and niece, and the survivors of them, and to the issue and issues of them respectively for their respective lives forever. . . ." Romilly, III. R., thought that the intention shown was to make a series of iife estates in perpetuity to the issue. In Hampton 2 . Holma $n^{\text {is }}$ the testator gave the benefit of a trust fund to his daughter for life, and directed that if she left children surviring her, the trustees should apply the income of the fund to the support and maintenance of such children equally, "during the term of their natural lives, and in like manner to their children and children's children. . . ." While the court did not directly decide the question, it was clearly of the opinion that no series of life estates was contemplated. Allyn 2 . Iathe $i^{\circ}$ was a case of a testamentary provision that after the death of the first life tenant the land should be equally divided between two grandsons of the testator "during their natural lives, and after their decease, to each of the eldest sons, lawfully begotten, and so from eldest son or sons forever; and in case they should have none, to the eldest male child of any of my three sons; and so from eldest to eldest to the end of time". The court held that the testator had attempted to create a series of life estates. ${ }^{\mathrm{C}} \mathrm{G}$

In all of the cases where the intention to create such a series of life estates has been found to exist, and also in Hampton $r$. Holmon, where the court decided against such an inference, the language has pointed much more clearly in that direction than in Ledwith $v$. Hurst. In the latter case the testator limited the property to the issue and "the survivor of such issue". He would not have used the word "survivor" unless he had reference to a class of lives existing concurrently. We do not speak of a grandchild born after the death of his grandfather as "surviving" him. The provision for per stirpes distribution among the issue also looks toward a single class and not toward a series of estates. Finally, the provision for sale at the death of the survivor and distribution to the charities, would seem to complete the case against the Pennsylvania court's apparent position. The testator directed distribution among four specific charities, doubtless selecting them because of his familiarity with, and his interest in, their work. Would he knowingly have made them a gift the benefit of which they might never realize because of the continuance to the end of time of this series of life estates? If he

63 (1867, Ch.) L. R. 4 Eq. Cas. 443.

of (1876) L. R. 5 Ch. D. 183.

es (1832) 9 Conn. 114.

68 For a discussion of the possibilities of cy pres in such cases, cee Gray, Rule against Perpetuities (3d ed. 1915) sec. 652. 
intended such a series, he must have supposed that it could be validly limited. Certainly such a construction should not be put upon his language in a doubtful case, where the effect of it is to defeat in large measure his entire purpose.

If it be determined in a given case that there is the intention to create such a series of life estates as has been referred to, then no doubt a remainder limited in fee thereafter will be void for remoteness under the rule of In re Mortimer. ${ }^{67}$ In that case there was a gift to an unborn child for life, a remainder in fee tail to the eldest son of that child, and (after intermediate limitations) a remainder in fee simple to the heirs of F. G., a person living at the death' of the testator. It is clear that the ultimate remainder to the heirs of F. G. would have vested at the latter's death, and so have escaped the operation of the Rule against Perpetuities unless the fact that it followed an invalid limitation in tail affected the vesting. It was held to be void. ${ }^{68}$

Fourth Construction: "Issue" in a Will May Mean "Children" of the Ancestor Referred to. If the word "issue" be construed as one of purchase, describing a class of persons who are to take immediately upon the death of a life tenant who is living at the death of the testator, all persons comprised within that class take vested interests not later than the death of the said life tenant, and so the gift to the class is valid as far as the Rule against Perpetuities is concerned. And if the issue take only life estates, no reason is perceived why a remainder limited thereafter to charities may not be regarded as a vested remainder, also perfectly valid. The mere fact that the life estates may last for more than lives in being and twenty-one years after the death of the testator does not invalidate a remainder limited after them. ${ }^{\circ 9}$ But it remains to inquire who the purchasers are that are included

87 (1905) L. R. 2 Ch. D. 502.

os Under the rule stated the gift to charities in Ledwith $v$. Hurst, supra note 1, was clearly bad if the court was correct in its apparent construction of the will as creating a series of life estates.

It is interesting to note Professor Gray's change of position in respect to the vested or non-vested character of a remainder limited after such a series. See Gray, op. cit. supra note 66 , at sec. 251 . It is not clear why the invalid life estates may not be disregarded entirely, with the consequential elimination of the condition precedent which deprives the romainder of its otherwise vested character.

Strangely enough, the Pennsylvania court itself seems to have denied in a dictum the conclusion reached in Ledwith $v$. Hurst as to the failuro of the gift to the charities. In In re Bingaman's Estato (1924) $281 \mathrm{~Pa}$. 497, 127 Atl. 173, the court said: "It is contended that . . . the gift in remainder to the hospital fell with the void particular estate. . . . This, however, is an erroneous conclusion . . . the gift to the hospital would be good, no matter what happens to the life estates, for that gift was vested, and was bound to go to the hospital at some future time." (Italics are the writer's).

${ }^{60}$ Gray, op. cit. supra note 66, at sec. 209. 
within the class, whether the "issue" are the children only of the ancestor referred to, or the grandchildren and more remote descendants as well who may be living at his death.

That "issue" may mean "children" and "children" only, is entirely clear. In Palmer v. Hor ${ }^{20}$ the testator gave a sum of money to be divided "into as many shares as there shall be lawful issuc of my deceased nephew, Matthew Horn, living at my death, and to invest and apply the income from each of the said shares to the use of each of the said children respectively, etc." It was properly held that "issue" meant children, as it was clear that the testator had used the two words symonymously. And in Craig v. Warneri1 a devise was made to J. E. C. for life, "and if the said J. E. C. shall . . . die leaving lawful issue, or lawful descendants of such children, . . . then I give to such issue, etc." Here again it was held that "issue" was equivalent to "children". Where a testatrix gave to her husband for life, and then to "my children, issue of my said husband and myself him surviving", the court decided that the meaning of "children" was not enlarged by use of the word "issue"::2 And in a number of other cases the court was more or less justified in construing "issue" to mean "children" upon the ground that the testator had used the words "issue" and "child" synonymously.:3 It has even been held that the use interchangeably of the words mentioned in another and entirely distinct gift in the same will warrants the construction as meaning "children"."*

A strong tendency is manifested in the English decisions to hold that the use of such words as "parent", "father", or "mother" correlatively with "issue" limits the meaning of the latter to "children". The leading case on this point is Sibley '. Pery,": decided by Lord Eldon in 1802. There the testator had given two legacies substantially in this form: "I give and bequeath to John . . . $\$ 1000$ stock as aforesaid if living at the time of my death, and to his lawful issue, share and share alike if the parent should then be dead." $\mathrm{He}$ also gave other gifts in this form: "I give to each of the lawful issue . . - of T. D. . . $£ 130$ stock as aforesaid if living at my decease". The

70 Supra note 46.

11 (1887, D.C.) 5 Mackey, 460. A similar construction of the same will was adopted in Craig v. Rowland (1897) 10 D. C. App. 402.

72 Greenfield v. Lauritson (1923) 306 Ill. 279, 137 N. E. 818.

${ }^{7}$ Stisser v. Stisser (1908) 235 Ill. 207, 85 N. E. 240; Faison 2. Odum (1907) 144 N. C. 107, 56 S. E. 793; Waller v. Mtilligan (1863) 45 Pa. 178; Parkhurst v. Harrower (1891) 142 Pa. 432, 21 Atl. 826. In Wcelawlece Ferry Co. v. Sisson, supra note 7, a grantor conveyed land to his son and to "such other lawful issue" as might be living. Held that there was nothing in this context to restrict "issue" to "children".

74 Iiddletown Trust Co. v. Gaffey, supra note 46.

75 (1802, Gh.) 7 Ves. Jr. 523. 
question was who should take under the name "issue" in a gift of the latter sort. It was declared that "issue" meant "children", the court reaching this conclusion from the use of the word "parent" in the gifts of the former type. Later decisions have established this rule in England..$^{76}$ But it has been subjected to vigorous criticism. In Ralph v. Carrick ${ }^{n 1}$ there was a gift to the children of Mrs. W., "the descendants, if any, of those who might have died being entitled to the benefit which their deceased parent would have received had he or she been then alive." There was a gift over if there should be no children or descendants. The court held that "descendants" did not mean "children". James, L. J., said: "I am not sure that some of the consequences of such a rule [i.e., that "issue" means "children"] have always received the attention they ought to have received. Suppose a man to leave his property to his wife for life, and at her death to all his children then living and the issue of such of them as should be then dead, equally to be divided between them, the issue of any of them who might be then dead to take only their parent's share. Suppose then his children all to die before the period of division, having had children who predeceased them leaving families. The grandchildren might go to the workhouse, and the family property go to a stranger under the residuary gift. That seems a possible result of that rule". ${ }^{88}$ The court then decided that Sibley v. Perry did not govern because there the word construed was "issue", while here the word was "descendants", a word not so easily confined to "children" by the context." It was further remarked that even though "issue" had been the word used, Sibley v. Perry would not have applied because the case at bar was indistinguishable from Ross $v$. Ross. ${ }^{80}$

The last mentioned case undoubtedly narrowed materially the

io Pruen v. Osborne (1840, Ch.) 11 Simons, 132; Martin v. Holgate (1866) L. R. 1 H. L. 175.

it Supra note 21.

is In the same case Brett, L. J., said: "I think, after the way in which Sibley v. Perry has been spoken of in subsequent decisions, we are not at liberty to say that it does not lay down a general rule. But I think the fate of that general rule will be the fate which usually accompanies $\mathfrak{a}$ rule which is not liked, namely, that it will be applied to cases exactly

like Sibley v. Perry, and to no others; or, in other words, it will bo no general rule at all, and, after hearing what the effect of such a general rule may be as described by Lord Justice James, I should have no objection to be present at the funeral of Sibley $v$. Perry."

70 James, L. J., said: "Now the word 'issue' is an ambiguous word. . . . But in this case there is what appears to me a perfectly unambiguous word-'descendants'-a word which I venture to say no layman or lawyer would use to designate children only. Descendants means children and their children and their children to any degree, and it is difficult to conceive any context by which the word 'descendants' could be limited to mean children only."

so (1855, Ch.) 20 Beav. 645. 
rule of Sibley $v$. Perry. The case presented for the consideration of the court was a gift of personalty in trust for C. R. for life, and after her decease on trust to transfer the same to "all and every the child and children of the said C. R. who shall be living at the time of her decease, and of the issue, if any, then living, of such of her children as may have died in her lifetime, each of her surviving children to take an equal share, and the issue, if more than one, of such of her children as may have died in her lifetime to take equally amongst them the part or share which their parent would have been entitled to, if he or she had survived the said C. R., and if but one, then to talie a child's shaic." There was a gift over if C. R. should die without leaving a child or issue of a child. The court was of the opinion that "issue" was not limited in meaning to "children". Its conclusion was based principally upon the gift over in default of issue, in which there was nothing to limit the meaning of "issue". It was thought that the testator could not have intended an intestacy while there was issue of $\mathrm{C}$. R. living, a result which might follow if the word "issue" was given a narrower significance in the gift to issue than in the gift over. On the other hand, if the scope of the word in the default clause was limited to "children", the effect might be to defeat a grandchild of $C$. $R$. and give the property over. This it was thought the testator could not have intended.82 Thus, while Ross $v$. Ross merely limited the rule of Sibley $v$. Pcrivy to cases where it was clear that the word "parent" was used strictly, and referred to the first taker, 82 it is apparent that the court was not in sympathy with the latter case. ${ }^{83}$

In this country the rule of Sibley $v$. Perry has received some direct support. A comparatively recent case in New Jersey,-

s1 In Ralph v. Carrick, supra note 21, also, much emphasis was put upon the default clause without anything in it to limit the meaning of "issue". James, L. J., said: "It is one of the most settled, and appears to me one of the most reasonable rules of construction, that where there is a gift over on the failure of certain persons the previous gift must, if the words reasonably admit of it, be construed as a gift to the same persons. Here it is beyond all question that the gift over is only to talke efrect upon an absolute failure of the descendants of all the aunts. There is nothing whatever to limit the words, and we are bound, unless there is something which absolutely compels us to the contrary, to suppose that the original gift was to the persons on failure of whom the gift over was to talie effect."

82 Romilly, M. R., said: "It is clear that the 'issue' of the 'parent' must mean the 'children' of the 'parent', but it is not certain, in every case (and it must be so before that rule can apply), that the testator has, by the word 'parent', meant to signify the first taker, the child in the first instance . . . it [word "parent"] might mean the child of the parent who would have been entitled, if that parent had survived $C$. $R$, that is to say, if one of the children had died leaving a child who had died leaving other children."

s: Compare also In re Orton's Trusts (1866) L. R. 3 Eq. Cas. $37 j$. 
Coyle v. Coyle, ${ }^{54}$-squarely sanctions it. But the case was based almost solely upon the English precedents, and evidently did not command the whole-hearted approval of the court. King $v$. Savage $^{85}$ was cited as an American precedent. An examination of that case will show that the court was not called upon to decide that "issue" meant children; it would have been enough to hold that the issue took per stirpes, and, therefore, that no children of living issue could participate. Moreover, it is clear from the later Massachusetts cases that the rule in that jurisdiction is now, at least, settled to the contrary. ${ }^{80}$ Taylor $v$. Taylor, ${ }^{87}$ a Pennsylvania case, is an authority for the English construction, by way of dictum only. There the testator gave to his daughter. S. B., for life, and after her death to her lawful issue, and further provided, "in case my daughter shall depart this life . . . leaving lawful issue, such issue shall inherit their mother's right from the time of her death." The court said: "No declaration could well be more express to show that by issue he meant children; for they were to inherit and enjoy 'their mother's right' from the time of her death." But all that the court had before it was the question, whether a purchaser from S. B. had received a clear title under a conveyance intended to bar the supposed entail. Two other Pennsylvania cases likewise seem to be but dicta. ${ }^{8 s}$. Austin $v$. Bristol ${ }^{80}$ has been cited as standing for the English rule..$^{00}$ But it is not at all certain that the case decided that point. The testator had given the residue of his estate to his wife for life, and at her death to "such of my children as may be living at the time of her decease, and to the issue of those who may have deceased, and to their heirs and assigns forever, to be equally divided between them; the issue of such deceased children to take per stirpes and not per capita." The testator had five children, one of whom predeceased him, leaving a child who survived the testator but died in the lifetime of the widow. It was held that although the gift to the children of the testator was contingent upon their surviving the life tenant, the gift to the issue vested immediately upon the death of the testator, so that the administrator of the deceased grandchild was entitled to her share. As there was nothing to divest a remainder once it vested, the practical result in the particular situation may have been to confine the gift to the child of the testator's deceased child. But suppose that at the death of the testator this grandehild had

84 (1907) 73 N. J. Eq. 528, 68 Atl. 224.

85 Supra note 49.

${ }^{86}$ See Massachusetts cases cited infra note 93.

87 Supra note 35.

s8 O'Rourle v. Sherwin (1893) 156 Pa. 285, 27 Atl. 43; Nice's Estatc, supra note 46.

89 (1873) 40 Conn. 120.

${ }^{\circ 0}$ Kales, op. cit. supra note 43. 
herself been dead, leaving a child surviving. Such surviving child would have been the gieatgrandchild of the testator, and the grandchild of the testator's child. Would not such greatgrandchild of the testator have been held entitled to a share in the property? It is true that the Connecticut court relied upon the English authorities ${ }^{21}$ holding that in such case the remainder to the issue was not contingent upon their surviving the life tenant, and that these English authorities did unquestionably regard "issue" in such cases as were before them to be the equivalent of "children"; but it does not seem that the Connecticut case can be fairly considered as an authority for the proposition that "issue" was restricted to "children", however much one may feel disposed to question the propriety of the decision as to the vested character of the remainder. It should be noted, moreover, that there was no correlative word such as "parent" present in this case. In a few other cases the English rule has been stated as one of several grounds for the decision, or has been approved in a dictum..$^{32}$

Against the above authorities are several clear-cut cases to the effect that "issue" is not restricted to "children" by the use of "parent" or equivalent words in connection with it.".3 That the meaning of "issue" is not limited to "children" in the absence of such correlatives as referred to, is generally admitted. ${ }^{04}$

Fifth Construction: "Issue" in a Will May Include All Descendants Living at the Time of Distribution. Having rejected the proposition that "issue" means "children", except in the case of a very special context, we would seem to come naturally to the conclusion that it includes descendants of all degrees living at the time of distribution. And this is, indeed, a very generally accepted rule. $^{95}$ It is, however, subject to some qualification, in many jurisdictions, as will be pointed out in more detail under the next head.

Sixth Construction: "Issue" in a Will May Include Only Such

91 IIartin $v$. Holgate, supra note 76.

92 Wallace v. Wallace (1925, Conn.) 130 Atl. 116; Gammell v. Eamat (1895) 19 R. I. 292, 33 Atl. 222; Amold $v$. Aldch (1895) 173 III. 220, 50 N. E. 704. And see also Chwatal v. Schiciner (1896) 148 N. Y. 683, 43 N. E. 166.

${ }^{93}$ Dester v. Inches, supra note 49 ; Hills 2. Barmard, supra note 59; Jacl:son v. Jackison, supra note 46; Trust Co. v. Dudloy, supra note 69; MIatter of Farmer's' Loan and Trust Co., supra note 49.

at Freeman v. Parsley, supra note 57; Stamford Tmest Co. 2. Loclwuod, supra note 49; Yarrington v. Frecman (1923) $201 \mathrm{Ky} .135$, 255 S. W. 1031; Trust Co. v. Dudley, supra note 59; Gardiner v. Evcrett, supra note 50; Willizs v. Rowan, supra note 28; Soper 2. Brown, supra note 21; Pctry 2 . Petry, supra note 59; Mattcr of Durant, supra note 49; Wcchawlicn Fcrm Co. v. Sisson, supra note 7; Wistar v. Scott, supra note 31; Rhode Icland Hospital Trust Co. v. Bridgham, supra note 15; Ridlcy v. McPhcrson (1897) 100 Tenn. 402,43 S. W. 772.

95 All of the cases cited in the preceding note may be deemed to stand 
Descendants Living at the Time of Distribution as Can Be Comprehended in a Per Stirpes Distribution. Where there are issue of different generations living at the time of distribution, many courts are disposed to hold that they take per stirpes-i. $e_{\text {., }}$ it is more consonant with the court's idea of fairness that they should take in that manner. This feeling is particularly strong where there are children of living descendants who would be included in a per capita distribution equally with their parents. Suppose there are two descendants of the first generation, one of whom has ten living children, who are, of course, themselves issue. If there is a per capita distribution, the property will be divided into twelve shares, eleven of which will go to one family, regarding each stirps and his issue as a "family". This result gives the impression of unfairness as between the two descendants of the first generation, and also as between the one descendant and his children, he taking but a single share, while they together take ten shares, though more remote from the ancestor. Many courts have struggled hard to avoid such a result. Of course, the question is one of the testator's intention; if he desired such a distribution, it must be had, unfair though it may be. Doubtless the truth of the matter is that usually the testator has never thought about such a possible situation. He thinks of the issue as a class without fixing his mind upon the individual members thereof; he looks only at the center of the picture, so to speak, seeing only the indubitable portion, and not that part which shades off into the background. In the occasional case where he has thought about the problem, he indicates his meaning more or less clearly; and the court eagerly lays hold of the slightest indication of intention. But what is to be done in the case where there is nothing which can be tortured into an expression of desire upon this point of per capita or per stirpes taking? The court must decide upon one or the other. Since by hypothesis "issue" includes descendants of all degrees, it is difficult to adont a mode of distribution which may eliminate some of them, as where there are children of living issue, although admitting others equally remote whose parent is dead. Where there is absolutely nothing which can be construed as a manifestation of the intention to have a per stirpes distribution, the authorities generally hold that it must be per capita, ${ }^{00}$ even though as a result children of living issue will take with their parents..$^{07}$

for this proposition, subject to the qualifications discussed in the following section.

96 Freeman v. Parsley, supra note 57; Yarrington v. Freeman, supra note 94; Price v. Sisson and Weehawken Ferry Co. v. Sisson, supra noto 7; Soper v. Brown, supra note 21; Schmidt v. Jewett, supra note 46; Petry v. Petry, supra note 59; Wistar v. Scott, supra note 31 ; Pearce v. Rickard, supra note 46; Ridley v. McPherson, supra note 94.

97 Freeman v. Parsley, supra; Price v. Sisson, supra; Petry v. Petry, supra; Pearcerv.-Rickard, supra; Ridley v. McPherson, supra. 
It may be instructive to examine a few typical cases to see what courts have regarded as sufficient indication of an intention to have a per stirpes distribution. First is that class of cases where the word "parent" or some equivalent expression is used in connection with the word "issue". While, as we have seen, this correlation of the two words is not always sufficient in this country to induce the construction of "issue" as meaning "children", it might be thought that it shows a desire on the part of the testator to have a per stirpes distribution. By declaring that the "issue" shall take the "parent's" share, the testator may mean that when any person who would take as "issue" if he survived the period of distribution dies, his descendants shall take the share he would have been entitled to had he survived. ${ }^{33}$ This view was strongly endorsed by the late $\mathrm{MI}$. Kales, who said: "The very fact that 'parent' does not turn issue into children means that 'parent' does not refer to the members of the original class who are to take and those alone, but refers to whoever may be a parent of any issue. The word 'parent' is thus used in a recurring or sliding sense so as to apply to successive generations of issue. When 'parent' is used in this sense, of course, the distribution can only be among those descendants who have no ancestors living and who stand in the place of their ancestors deceased." 99 Mrr. Willard Brooks has replied to this suggestion in the following words: "It is perhaps conceivable that when a testator says 'such issue to take the parent's share', he had in mind many groups, each group being the issue of any member of the original 'issue', each of these sub-grouns, therefore, taking its immediate ancestor's share. But whether conceivable or not, such an inference is, to say the least, highly improbable. As a fiction, if it were a good one, we might still adopt it; but the limits of common-sense should not be stretched to such an extent as to imagine that the testator actually intended this 'recurring or sliding sense'. Can there be any real question but that when he speaks of 'such issue' and the 'parent' of the same, he means a single ancestor?" 100 It must be conceded that there is much force in this answer. In cases like Ross $v$. Ross, supra, where the cortext has deterred the court from holding that "parent" makes

${ }^{98}$ In Ross $v$. Ross, supra note 80, Romilly, MI. R., said: "The whole thing is set right . . . if you refer the word 'parent' there to such one of the children of the children of $C$. $R$., that is, to the grandchildren of C. $R$., who, if that parent had lived, would have taken the share which the child of C. R., if that child had lived, would have talien, that is to say, it carries on the distribution per stirpcs, not merely through the first degree, but extending it even to the second."

s9 Kales, op. cit. supra note 43, at sec. 580; and see also, Theobald, op. cit. supra note 11 , at 319 .

100 Brooks, Meaning of the Word "Issue" in Gifts to "Issuc"-Another" View (1911) 6 ILL. L. REv. 230, 232. 
"issue" mean "children", the English judges have attributed to the testator the intention to have a per stirpes distribution. So in that case, where there survived the life tenant, to whose "issue" the gift was made, three children, the children of a deceased child, and a grandchild of a fifth child, also deceased, it was held that the grandchild was entitled to one-fifth of the property, that being the share to which his grandparent would have been entitled had he survived. And there are several decisions in this country attaching like importance to the use of the word "parent". ${ }^{101}$

There have been a few cases in which it would seem that the testator has indicated his intention beyond doubt in favor of a per stirpes distribution. In Robins $v$. Quinliven ${ }^{102}$ the gift to the issue was declared to be "in the proportion to which they would be entitled under the intestacy laws of Pennsylvania." If, as is usually the case, the statute of descents and distributions provides that heirs of unequal degree shall take per stirpes, there can be no doubt as to the correct result in such a case. So, also, in Green $v$. Hussey, ${ }^{103}$ where the testator gave to the lineal descendants of G. H., and then provided "If all the lineal descencants aforesaid then living are in the same degree of kindred to the said G. H., they shall share the estate equally and shall be paid in equal shares; otherwise they shall take according to right of representation." G. H. had eleven children, forty-five grandchildren and numerous greatgrandchildren. At the time for distribution three grandchildren and many greatgrandchildren survived. It was properly held that the property must be divided into forty-five shares. Likewise there should be a per stirpes distribution where the will provides for a gift "in equal shares to the then living children or lineal descendants by right of representation of my six brothers, etc." 104 Now it should be noted that Ledwith v. Hurst is a case of this type, for the testator expressly declared that division among the issue should be "per stirpes". ${ }^{105}$ Cushney v. Henry ${ }^{106}$ was a somewhat peculiar case. The testatrix provided that on the death of the survivor of her three children a trust estate should be sold, and the proceeds divided among the "issue" of those children. If all of the said children left issue, one-third part of the proceeds was to be paid to the issue of each; if but two left issue, one-half to the issue of

101 See cases cited supra note 93.

102 Supra note 23.

103 Supra note 59.

${ }^{104}$ In re Dalrymple's Will (1921) 173 Wis. 464, 180 N. W. 829.

${ }^{105}$ In Gourdin v. Deas, supra note 23, there was a deed to the issuo to take "per stirpes". It was held that the gift vested in the issue of the first generation living at the date of the deed, and the descendants of those deceased.

${ }^{106}$ Supra note 59. 
each; and if but one left issue, that issue to take the whole. The issue were always to take as tenants in common. And then it was further provided that if any child of the sons or daughter of the testatrix should have died in the lifetime of its parcat, leaving issue, which issue should be living at the death of the survivor of the children of the testatrix, then such issue should stand in the place of and take such part of the estate as his, her or their porent would have been entitled to if living. It was held that there should be per stirpes distribution even though all the surviving issue were greatgrandchildren of the testatrix. It would seem in this case that the testatrix expressly provided for per stirpes distribution only as to the first generation of issue; the decision carried it into the second generation. Fet this would seem a proper result, for it is evident that the testatrix had sueh a manner of division in mind and expressed her desire with respect to the concrete situation she thought would likely arise; there is every, reason to suppose that she would have desired a similar result in the circumstances as they actually developed.

There is a large class of cases where the court has professed to see the intention for a per stirpes distribution, but where the evidence of such intention is very slight, indeed. In Stamford Trust Co. v. Lockwood"10z the testator gave to the "lawful issue" of two grandchildren, and then provided that if both should die without issue surviving, he gave to the "issue" of three of his children, "per stirpes". From the use of these words in the gift over the court inferred the intention to have a per stirpes division among the issue of the first donees. In $R$ cmbcit $i$. Vetoe ${ }^{108}$ there was a gift for life, with remainder to the "issue". Then followed a gift over on death without issue to the next of kin of the testator "according to the statute of distribution of intestate estates". It was held that division among the issue of the frrst donee should be per stirpes, so as to exclude children of living issue. Perhaps one would not be disposed to criticise severely the result in these two cases; there was evidence which may have justified the inferences drawn.

There are a number of decisions in New York which show how far a court is willing to go in the indulgence of its preference for a per stirpes distribution, and yet feel the necessity for justifying its action on the ground of an alleged intention of the testator. In Matter of Farmers' Loan and Trust Co. ${ }^{100}$ there was a gift to F. M. for life, and then to his "issue", with a gift over in event of no issue. F. MI. died leaving two daughters and four grandchildren who were the children of these daughters. The court found an intention to give to the issue per stirpes because

107 Supra note 49.

108 Supra note 37.

103 Supra note 49. 
in another clause of the will the testator had provided that if any of his children should die before division of his estate, then he gave the share of such children to their "issue", to take equally "what would have been the parent's shares". In re Lawrence's Estate" $^{110}$ was the case of a gift to the issue of C. L. M., but "if she shall die without leaving lawful issue, then her share shall go to increase the shares of my other children and their legal representatives." The court here found a "faint glimpse" of intent to give per stirpes, in the reference to "legal representatives" in the gift over. In Matter of Durant ${ }^{111}$ a gift was given in trust for a daughter for life and then to her "issue". The testator had given legacies to his sons absolutely, but with the provision that if they should die before him without leaving issue, then the property should go to others. Now under the New York statute a legacy did not lapse if the legatee left issue; therefore the court inferred from the fact that there was a gift over if the legatee did not leave issue that the testator had the statute in mind, and intended a distribution among the issue per stirpes in all cases.

Occasionally a testator makes a gift to "the children of $\mathrm{A}$ and the issue of any deceased child", associating the issue in the same gift with persons of equal degree to the ancestor. A recent case of this type is Matten of Lawrence, ${ }^{112}$ where property was directed to be divided on the death of a life tenant among "my sisters, nephews and nieces and issue of my nephews and nieces dying prior to the death of (the life tenant)." On the death of the life tenant there were four nephews and nieces and five children of a deceased niece. It was held that the nephews and nieces and issue took per stirpes, because it was clear that the issue were to take "only in event that the parent had died." The decisions on this type of case almost always reach the same result.113 It may be doubted whether there is actually any more evidence of intention on the part of the testator in this case than in those previously discussed. But the close association of the issue with persons of nearer degree makes the supposed injustice of a per capita distribution more striking. The further question may arise in this situation whether the issue are to take per stirpes only with reference to other members of the class who

110 Supra note 49.

111 Supra note 49.

112 Supra note 46.

113 See cases cited in Kales, op. cit. supra note 43 , at sec. 579 , and noto 15. See also: In re Dalrymple's Will, supra note 104, where the gift was to "the then living children or lineal descendants by right of representation, etc."; In re Hickey, supra note 21, where the gift was to "the descendants of my aunt A. S. or their descendants living at my death". A. S. had children, grandchildren, and greatgrandehildren living at the death of the - testator; the court found in the repetition of the word "descendants" a stirpetal significance. 
are not "issue", or whether the issue are to take per stirpes as among themselves. Suppose in Matter of Lawrcince, supi $a$, one of the five children of the deceased niece had been dead, leaving children? Would the children and grandchildren of the decensed niece have taken the latter's share per stirpes?'s

If, as has already been suggested, the testator does not have in mind any definite meaning for the word "issue" as he uses it, it might be thought that the court is free to give it whatever meaning will most likely be consonant with what his intention would have been had he actually turned his mind to the point. In other words, the question might be stated thus,_- "What construction will most nearly approximate the probable desires of the largest number of testators as to the effect of their gifts to "issue" "? If we believe that the average testator who thinlis about the point specifically decides in faror of a per stirpes distribution, why should there not be a rule that such is the prima facie meaning of the gift? MIr. Kales has said that to attribute the stirpetal significance to a gift where there is no special context to indicate such intention is to give "an unusual and highly complex meaning to a single word." He says further: "The word 'issue' is being made to stand elliptically for much more than is contained in the word itself." This would seem to assume that there is some fixed meaning for the word whieh everyone knows and agrees to. As already pointed out, it is an error to suppose that the testator had a definite and fised neaning in mind. The question is what meaning the cortit shall give to the word in order best to effectuate his vaguely comprehended scheme of distribution.

That there is a decided tendency toward a rule that in every gift to "issue" the prima facie construction is in favor of a per stirpes division, cannot be doubted. The leaning of the New York court is very markedly in this direction, as the cases previously discussed indicate, although the result may be veiled behind some "faint glimpse" of testamentary intention. perceived by the court. Perhaps the most conspicuous drift toward the rule suggested is in Massachusetts. Reference has already been made to the decisions in that state requiring a per stirpes distribution because of the use of the word "parent". ${ }^{85}$ In Eiarst $v$. Rivers ${ }^{116}$ there was a gift to "the lineal heirs of $\mathrm{L} . \mathrm{S}$. $\mathrm{R}$ ". In holding that the greatgrandchildren of L. S. R. were entitled, and that their children could not participate, the court said: "It is a general rule of construction to be followed razless the testatoi" has clearly manifested a contrary intention that a devise or be-

114 See further on this point, Kales op. cit. supra note 43 , at rees. 579 and 583 .

115 Supra notes 101 and 93.

110 Supra note 59. 
quest to 'heirs' or 'issue' refers to that class of beneficiaries who would be entitled to take under the law of intestate succession. if the designated ancestor had died at the time fixed for ascertaining the class, and also indicates that the members of the class so determined are to share in the same manner and proportions as such persons would share under the statute relating to the distribution of intestate estates. - . . Where a gift is made to members of a class described as 'heirs' or 'issue' in accordance with the rule last above stated it is held that grandchildren and their descendants will not be allowed to compete with their parents unless such was the intention of the testator. We find no such intention on the part of the testator in the case at bar - . ".11 Rembert $v$. Vetoe, supra, is a very interesting decision. As has been previously suggested, ${ }^{118}$ the result in that case might have been put on the ground of an intention of the testator manifested in the gift over on default of issue. But the court said that whenever there was a gift to "heirs of the body", it was necessary to resort to the statute of descents to find out who those persons were; "No one can take as heir of the body of another, unless he fulfills the description, and is not only such a person as would take the real estate of that other under our act of distributions, but likewise a lineal descendant." The court then declared that "issue" was equivalent to "heirs of the body"; therefore "issue" had to be construed in the light of the statute, which required per stirpes distribution among lineal descendants. In Stamford Trust Co. v. Lockwood, supra, it was possible again to uphold the decision on the ground of intention made manifest in the gift in default. But the court said, quoting with approval from an earlier case: "s. . . in the absence of words indicating a contrary intent, a will is to be interpreted as intending to distribute an estate per stirpes, and in accordance with the statute of distributions. "A further consideration in favor of the per stirpes rule is, that this rule has for two centuries commended itself to the judgment of the community as one of justice, and has been and is the rule applied by the law in case of intestate estates. In these circumstances this rule will be applied in the construction of a will where the language of the will leaves the intent of the testator in serious doubt." ", In Rhode Island Hospital Trust Co. $v$. Bridgham ${ }^{110}$ the court overruled a former precedent ${ }^{120}$ and directed a per stirpes distribution, being influenced, not only by its feeling of the

117 Italics are the writer's. See also: Jackson v. Jackson, supra note 46; Coates v. Burton (1906) 191 Mass. 180, 77 N. E. 311; Gardiner v. Evorett, supra note 59.

118 See supra in the text of note 37.

110 Supra note 15.

${ }^{120}$ Pearce v. Rickard, supra note 46. 
greater justice in that method, but also by a statute of the state which provided that whenever a devise or bequest was made to one for life and thereafter to his "issue", the word "issue" should be construed to mean the children of the life tenant living at his death, and the lineal descendants of such children as may have died, such descendants taking equally among themselves the share which their deceased parent would have taken. This statute was obviously an attempt to abrogate, in part, at least, the Rule in Shelley's Case, and did not cover the case at bar. But the court thought that it did declare a legislative policy as to the proper construction for the word "issue", and that it was desirable to have the same construction given whether the gift was to the issue after a life estate to the ancestor, or otherwise.

Granting in a given case that distribution is to be per stirpes, who are the stirps? Let us suppose the typical case of a gift to A for life, and after his death to his issue, with a context excluding application of the Rule in Shelley's Case. A had two sons, both of whom predeceased their father, one son leaving two children surviving the testator; and the other, three children, and also two children of a deceased child. Is the property to be divided into two shares, one to go to the issue of each deceased son of $A$ ? Or is it to be divided into six shares, one for each grandchild of A or his issue? It has been remarlied already that there is a strong tendency to rely upon the analogy of the statutes of descent. Not infrequently those statutes expressly provide for, or have been construed to require, division cqually amoing a!! descendants of equal degree. In our supposititious case this would result in six shares rather than two. It cannot be said that the cases throw much light upon this question. ${ }^{121}$

Considered with respect to the preceding discussion, there can be little doubt that Ledwith $v$. Huist was wrongly deeided. The context made it apparent that the testator had used "issue" as a word of purchase, and purchase only. There was no sufficient indication of an intention to create a perpetual series of life estates. Nor was there anything in the language to restrict "issue" to "children". The gift should have been held, therefore, to give life estates to the descendants of Mary Ledwith who survived her, they taking per stirpes according to the express provision of the will, with a valid remainder to the charities.

In conclusion the witer ventures the suggestion that two developments may be looked for in the future decisions upon the construction of "issue"-that an increasing number of courts will lay it down as a rule of prima facie construction that in $\mathfrak{a}$ will

${ }^{121}$ In Dexter $v$. Inches, supra note 49 , it is suggested that the stirps may be the issue of the nearest degree represented at the time for distribution. Compare the Rhode Island statutory provision referred to in the text supra of note 119. 
the word is one of purchase; and that in the absence of indication of a contrary intention the division among the class taking is to be per stirpes. Estates tail in this country are practically extinct; and the learning connected with them is fast fading from the minds of bench and bar. The general feeling of the justice of a per stirpes distribution and the influence of the analogy of the statutes of descent will undoubtedly be potent factors in new cases. 